\title{
EXPERIMENTAL STUDY OF THE Y-Cu-Ge SYSTEM AT 870 K
}

\author{
Mariya Konyk ${ }^{1}$, Lyubov Romaka1, ${ }^{凶}$, Pavlo Demchenko', Vitaliy Romaka ${ }^{1,2,3}$, \\ Volodymyr Krayovskyy ${ }^{2}$, Mariya Rokomanyuk ${ }^{2}$
}

https://doi.org/10.23939/chcht14.02.177

\begin{abstract}
The phase equilibrium diagram of the $\mathrm{Y}-\mathrm{Cu}-$ Ge ternary system was constructed at $870 \mathrm{~K}$ by X-ray diffractometry, metallographic and electron probe microanalyses over the whole concentration range. Formation of six ternary compounds $\mathrm{YCuGe}$ (LiGaGe-type), $\mathrm{YCu}_{2} \mathrm{Ge}_{2}\left(\mathrm{CeAl}_{2} \mathrm{Ga}_{2}\right.$-type), $\mathrm{Y}_{3} \mathrm{Cu}_{4} \mathrm{Ge}_{4}\left(\mathrm{Gd}_{3} \mathrm{Cu}_{4} \mathrm{Ge}_{4}\right.$-type $)$, $\mathrm{Y}_{2} \mathrm{CuGe}_{6}\left(\mathrm{Ce}_{2} \mathrm{CuGe}_{6}\right.$-type), $\mathrm{YCu}_{0.67} \mathrm{Ge}_{1.33} \quad\left(\mathrm{AlB}_{2}\right.$-type), and $\mathrm{YCu}_{0.3} \mathrm{Ge}_{2}\left(\mathrm{CeNiSi}_{2}\right.$-type) were observed.
\end{abstract}

Keywords: intermetallics, phase diagrams, X-ray diffraction, crystal structure.

\section{Introduction}

Phase equilibrium diagrams of the metallic systems at selected temperatures reveals an information on the formation, stability, composition, and homogeneity range of the intermetallic compounds and the heat treatments necessary to obtain homogenous phases. A systematic description of the R-T-Ge phase diagrams and the structural characteristics of the formed intermediate phases (Rrare earth, T- $d$-element) have been presented in [1]. As regards the $\mathrm{R}-\mathrm{Cu}-\mathrm{Ge}$ systems, the most studied compounds are $\mathrm{RCuGe}\left(\mathrm{LiGaGe} / \mathrm{CaIn}_{2}, \mathrm{AlB}_{2}\right.$ structure types) [2], $\mathrm{R}_{3} \mathrm{Cu}_{4} \mathrm{Ge}_{4}\left(\mathrm{Gd}_{3} \mathrm{Cu}_{4} \mathrm{Ge}_{4}\right.$-type $)$ [3], $\mathrm{RCu}_{2} \mathrm{Ge}_{2}\left(\mathrm{CeAl}_{2} \mathrm{Ga}_{2^{-}}\right.$ type) [4], $\mathrm{R}_{2} \mathrm{CuGe}_{6}\left(\mathrm{Ce}_{2} \mathrm{CuGe}_{6}\right.$-type) [5]. According to Jandelli et al. [2] the $\mathrm{RCuGe}$ compounds containing $\mathrm{R}$ $=\mathrm{La}-\mathrm{Gd}$ (except for $\mathrm{Eu}$ ) belong to the $\mathrm{AlB}_{2}$-type structure while those containing $\mathrm{R}=\mathrm{Tb}-\mathrm{Lu}$ crystallize with the disordered $\mathrm{CaIn}_{2}$ structure type. In $[6,7]$ a single crystal investigation of the $\mathrm{GdCuGe}$ and $\mathrm{YbCuGe}$ compounds revealed ordered $\mathrm{NdPtSb}$ structure type (space group $\left.P 6_{3} m c\right)$. Two ternary separated phases $\left(\mathrm{SmCu}_{1.3} \mathrm{Ge}_{0.7}\right.$, $\mathrm{SmCu}_{0.62-0.44} \mathrm{Ge}_{1.38-1.56}$ ) with $\mathrm{AlB}_{2}$ type structure were identified in the Sm-Cu-Ge system at $870 \mathrm{~K}$ [8]. Further

\footnotetext{
${ }^{1}$ Department of Inorganic Chemistry, Ivan Franko Lviv National University,

6, Kyryla i Mephodiia St., 79005 Lviv, Ukraine

${ }^{2}$ Lviv Polytechnic National University,

12, S. Bandera St., 79013 Lviv, Ukraine

${ }^{3}$ Institute for Solid State Research, IFW-Dresden,

20, Helmholtzstr., 01069 Dresden, Germany

凶lyubov.romaka@lnu.edu.ua

(C) Konyk M., Romaka L., Demchenko P., Romaka V., Krayovskyy V., Rokomanyuk M., 2020
}

investigations of the $\mathrm{RCuGe}$ germanides, where $\mathrm{R}=\mathrm{Tb}$ $\mathrm{Er}$, using the neutron diffracttion data allowed to refine the crystal structure more precisely in the LiGaGe-type (space group $\mathrm{Pb}_{3} \mathrm{mc}$, an ordered non-centrosymmetric variant of the $\mathrm{CaIn}_{2}$-type with full occupancy of all atomic positions) [9].

Other series of intermetallic compounds $\mathrm{RCu}_{1-x} \mathrm{Ge}_{2}$ with defect $\mathrm{CeNiSi}_{2}$-type have been identified previously for the most rare earths [10]. Analysis of the literature data showed that the R-Cu-Ge phase diagrams, where $\mathrm{R}$ are rare earths of Yttrium group, were studied for $\mathrm{R}=\mathrm{Tb}, \mathrm{Er}$, $\mathrm{Yb}$, and $\operatorname{Tm}[1,11,12]$.To our knowledge, no information is available on the phase diagram of the system $\mathrm{Y}-\mathrm{Cu}-\mathrm{Ge}$. Some intermetallics of yttrium with copper and germanium as representatives of isostructural series have been studied only [1].

In this paper we present for the first time the results of X-ray and EPM analyses of the phase equilibria in the $\mathrm{Y}-\mathrm{Cu}-\mathrm{Ge}$ ternary system at $870 \mathrm{~K}$ over the whole concentration range and the crystal structure data for the ternary compounds.

The data of the Y-Ge, Y-Cu and Cu-Ge binary systems that delimit the studied $\mathrm{Y}-\mathrm{Cu}-\mathrm{Ge}$ system were taken from Refs. [13-15]. Six binary phases exist in the Y$\mathrm{Ge}$ system at $870 \mathrm{~K}: \mathrm{Y}_{5} \mathrm{Ge}_{3} \quad\left(\mathrm{Mn}_{5} \mathrm{Si}_{3}\right.$-type $), \mathrm{Y}_{5} \mathrm{Ge}_{4}$ ( $\mathrm{Sm}_{5} \mathrm{Ge}_{4}$-type), $\mathrm{Y}_{11} \mathrm{Ge}_{10}\left(\mathrm{Ho}_{11} \mathrm{Ge}_{10}\right.$-type), YGe (TlJ-type), $\mathrm{YGe}_{1.67}$ (own type), $\mathrm{Y}_{3} \mathrm{Ge}_{5}$ (own type). Additionally, compound $\mathrm{Y}_{3} \mathrm{Ge}_{4}(870 \mathrm{~K}, 1070 \mathrm{~K})$ with $\mathrm{Er}_{3} \mathrm{Ge}_{4}$-type was reported in Ref. [16]. The $\mathrm{Y}-\mathrm{Cu}$ binary system is characterized by the formation of five compounds: $\mathrm{YCu}_{5}$ ( $\mathrm{CaCu}_{5}$-type), $\mathrm{Y}_{0.8} \mathrm{Cu}_{5.4}\left(\mathrm{~Tb}_{0.78} \mathrm{Cu}_{5.44}\right.$-type), $\mathrm{YCu}_{2}\left(\mathrm{KHg}_{2^{-}}\right.$ type), $\mathrm{YCu}$ (CsCl-type), and $\mathrm{Y}_{2} \mathrm{Cu}_{7}$ with unknown structure. Three phases have been observed in the binary system $\mathrm{Cu}-\mathrm{Ge}$ [13], for $\mathrm{Cu}_{3} \mathrm{Ge}$ germanide polymorphic transition occurs near $923 \mathrm{~K}$ from the low-temperature modification with $\mathrm{TiCu}_{3}$-type to the high-temperature one with the $\mathrm{IrAl}_{3}$-type. Differently from the compounds in the $\mathrm{Y}-\mathrm{Ge}$ and $\mathrm{Y}-\mathrm{Cu}$ systems (except $\mathrm{Y}_{0.8} \mathrm{Cu}_{5.4}$ and $\mathrm{YCu}_{5}$ ), the copper germanides have significant homogeneity ranges.

\section{Experimental}

The polycrystalline samples were prepared by an arc-melting of the constituent elements (yttrium, purity of 
99.9 wt \%; copper, purity of $99.99 \mathrm{wt} \%$; and germanium, purity of 99.999 wt \%) under protected argon atmosphere (Ti as getter) on a water-cooled copper bottom. For better homogenization the samples were melted twice. The weight losses of the initial total mass were lower than $1 \mathrm{wt} \%$. The pieces of the as-cast buttons were annealed for one month at $870 \mathrm{~K}$ in evacuated silica tubes and then water quenched. Annealed samples were characterized through their X-ray powder patterns. Phase analysis was performed using X-ray powder diffractions of the synthesized samples (DRON-4.0, Fe $K_{\alpha}$ radiation). The observed diffraction intensities were compared with reference powder patterns of the pure elements, binary and known ternary phases. The chemical compositions of the obtained samples were examined by scanning electron microscopy (SEM). For the microstructural studies the specimens were prepared by standard metallographic procedures (automatic grinding and polishing) followed by colloidal silica polishing for $5 \mathrm{~min}$. The microstructures were examined by Schotky field emission scanning electron microscope (SEM: JEOL JSM-7600F) equipped with an energy-dispersive spectroscopy (EDS) X-ray analyser: Oxford Instruments X-max $50 \mathrm{~mm}^{2}$. Microscope parameters for sample observation in (COMPO mode) and EDS chemical analysis was set at $15 \mathrm{kV}$.

XRPD data for structure refinements were collected in the transmission mode on a STOE STADI $P$

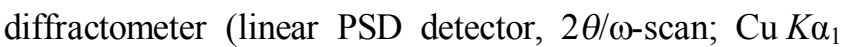
radiation, curved germanium ( $\left.\begin{array}{llll}1 & 1 & 1\end{array}\right)$ monochromator). Calculations of the crystallographic parameters were performed using Fullprof Suite program package [17].

The microhardness was measured using a Microhardness Tester (FM-100, Future-Tech Corporation). The square-based pyramidal diamond was pressed using a force of $44.5 \mathrm{~N}$ for a loading time of $10 \mathrm{~s}$; at least eight areas across each joint were tested in our measurements to obtain an average value.

\section{Results and Discussion}

\subsection{Isothermal Section of the $\mathrm{Y}-\mathrm{Cu}-\mathrm{Ge}$ System}

To establish the phase relations in the $\mathrm{Y}-\mathrm{Cu}-\mathrm{Ge}$ ternary system 38 binary and ternary alloys were prepared, annealed and examined by X-ray powder diffraction and Electron probe microanalysis (EPMA). Constructed isothermal section of the Y-Cu-Ge system at $870 \mathrm{~K}$ over the whole concentration range is presented in Fig. 1. The phase composition and EPMA data for selected alloys are summarized in Table 1, microphotographs are shown in Fig. 2. The measured overall compositions of the alloys are close to the nominal ones within 1-2 at \%.

In the $\mathrm{Y}-\mathrm{Cu}, \mathrm{Y}-\mathrm{Ge}$ and $\mathrm{Cu}-\mathrm{Ge}$ binary systems the presence of all binary compounds corresponding to the reference data [13-16] was confirmed at the temperature of investigation (Fig. 1). However, $\mathrm{Y}_{2} \mathrm{Cu}_{7}$ phase was not identified at the annealing temperature; corresponding sample contained the $\mathrm{YCu}_{5}$ and $\mathrm{YCu}_{2}$ binaries in equilibrium. To check the formation of a solid solution based on the $\mathrm{Y}_{5} \mathrm{Ge}_{3}\left(\mathrm{Mn}_{5} \mathrm{Si}_{3}\right.$-type $)$ binary compound the alloys up to composition $\mathrm{Y}_{56} \mathrm{Cu}_{11} \mathrm{Ge}_{33}$ were prepared. Phase analysis of the corresponding samples and the systematic analysis of their cell parameters did not indicate a solubility of $\mathrm{Cu}$ in the $\mathrm{Y}_{5} \mathrm{Ge}_{3}$ compound at investigated temperature. EPMA data showed that corresponding samples belong to two- or three-phase fields (Table 1, Fig. 2). The solubility of the third component in all binary compounds is less than $1.5-2$ at \% under applied conditions.

In the course of our studies the existence of the previously known $\mathrm{YCuGe}, \mathrm{YCu}_{2} \mathrm{Ge}_{2}, \mathrm{Y}_{3} \mathrm{Cu}_{4} \mathrm{Ge}_{4}$, and $\mathrm{Y}_{2} \mathrm{CuGe}_{6}$ compounds was confirmed at $870 \mathrm{~K}$. An analysis of the alloys along isoconcentrate of 33 at \% Y showed that the $\mathrm{YCuGe}$ compound was realized at equiatomic composition, and the ternary phase with $\mathrm{AlB}_{2}-$ type was identified in the sample at $\sim \mathrm{Y}_{33} \mathrm{Cu}_{22} \mathrm{Ge}_{45}$ composition $\left(\mathrm{YCu}_{0.67} \mathrm{Ge}_{1.33}\right)$. No homogeneity range was observed for this phase. By the results of the X-ray phase and EPM analyzes of the samples in the Ge-rich part of the $\mathrm{Y}-\mathrm{Cu}-\mathrm{Ge}$ system the new ternary compound at composition $\mathrm{Y}_{30} \mathrm{Cu}_{10} \mathrm{Ge}_{60}$ was found. The crystallographic parameters of the formed ternary compounds are given in Table 2.

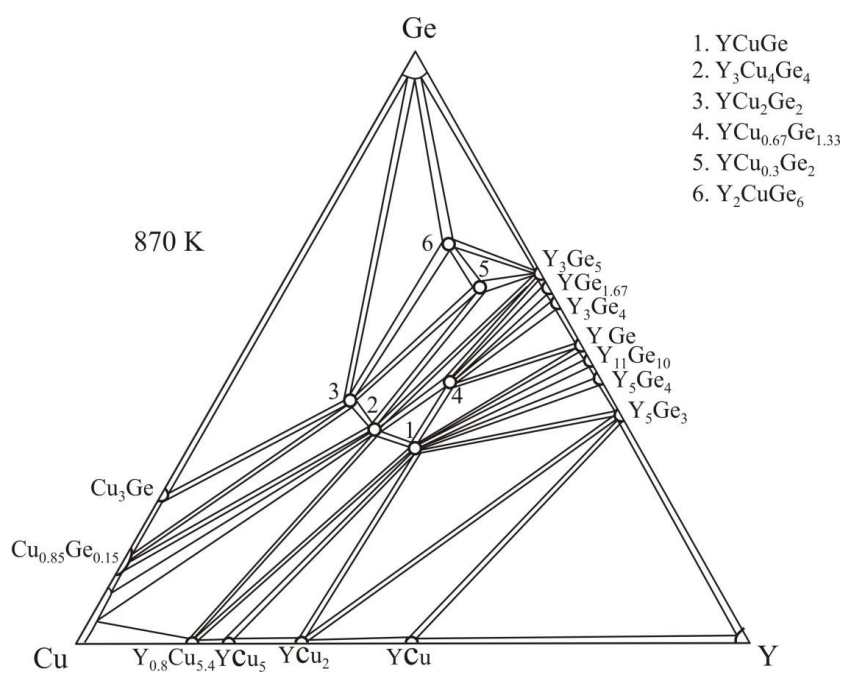

Fig. 1. Isothermal section of the Y-Cu-Ge system at $870 \mathrm{~K}$ 
Table 1

Phase composition of the selected Y-Cu-Ge alloys

\begin{tabular}{|c|c|c|c|c|}
\hline \multirow{2}{*}{$\begin{array}{c}\text { Nominal alloy composition, } \\
\text { at } \%\end{array}$} & \multicolumn{3}{|c|}{ Composition from EPMA data, at $\%$} & \multirow{2}{*}{ Phases } \\
\hline & $\mathrm{Y}$ & $\mathrm{Cu}$ & $\mathrm{Ge}$ & \\
\hline (a) $\mathrm{Y}_{62.5} \mathrm{Cu}_{7} \mathrm{Ge}_{30.5}$ & 62.26 & 6.94 & 29.80 & $\begin{array}{c}\mathrm{Y}_{5} \mathrm{Ge}_{3} \text { (light grey, } \mathrm{Y}_{65.22} \mathrm{Ge}_{34.78} \text { ) } \\
\mathrm{YCu} \text { (grey, } \mathrm{Y}_{51.74} \mathrm{Cu}_{48.26} \text { ) } \\
\text { (Y) (dark) }\end{array}$ \\
\hline (b) $\mathrm{Y}_{62.5} \mathrm{Cu}_{3} \mathrm{Ge}_{34.5}$ & 63.55 & 3.25 & 33.20 & $\begin{array}{c}\mathrm{Y}_{5} \mathrm{Ge}_{3} \text { (light, } \mathrm{Y}_{65.05} \mathrm{Ge}_{34.95} \text { ) } \\
\mathrm{YCu}\left(\text { grey, } \mathrm{Y}_{50.18} \mathrm{Cu}_{49.82} \text { ) }\right.\end{array}$ \\
\hline (f) $\mathrm{Y}_{62.5} \mathrm{Cu}_{10} \mathrm{Ge}_{27.5}$ & 59.61 & 9.76 & 30.63 & $\begin{array}{l}\mathrm{Y}_{5} \mathrm{Ge}_{3}\left(\text { light, } \mathrm{Y}_{64.11} \mathrm{Ge}_{35.89}\right) \\
\left.\mathrm{YCu} \text { (grey, } \mathrm{Y}_{46.01} \mathrm{Cu}_{53.99}\right)\end{array}$ \\
\hline (e) $\mathrm{Y}_{62} \mathrm{Cu}_{15} \mathrm{Ge}_{23}$ & 61.73 & 12.08 & 26.19 & $\begin{array}{c}\mathrm{Y}_{5} \mathrm{Ge}_{3} \text { (light, } \mathrm{Y}_{64.81} \mathrm{Ge}_{35.19} \text { ) } \\
\mathrm{YCu} \text { (grey, } \mathrm{Y}_{46.01} \mathrm{Cu}_{53.99} \text { ) } \\
\text { (Y) (dark) }\end{array}$ \\
\hline (c) $\mathrm{Y}_{50} \mathrm{Cu}_{30} \mathrm{Ge}_{20}$ & 47.10 & 29.65 & 23.25 & $\begin{array}{l}\mathrm{Y}_{5} \mathrm{Ge}_{3}\left(\text { light, } \mathrm{Y}_{64.28} \mathrm{Ge}_{35.71}\right) \\
\mathrm{YCu}_{2}\left(\text { grey, } \mathrm{Y}_{33.44} \mathrm{Cu}_{66.56}\right)\end{array}$ \\
\hline (d) $\mathrm{Y}_{50} \mathrm{Cu}_{40} \mathrm{Ge}_{10}$ & 48.91 & 38.96 & 12.13 & $\begin{array}{c}\mathrm{Y}_{5} \mathrm{Ge}_{3}\left(\text { light, } \mathrm{Y}_{64.02} \mathrm{Ge}_{36.98}\right) \\
\mathrm{YCu}\left(\text { grey, } \mathrm{Y}_{50.25} \mathrm{Cu}_{49.75}\right) \\
\mathrm{YCu}_{2}\left(\text { dark grey, } \mathrm{Y}_{33.64} \mathrm{Cu}_{66.36}\right)\end{array}$ \\
\hline
\end{tabular}
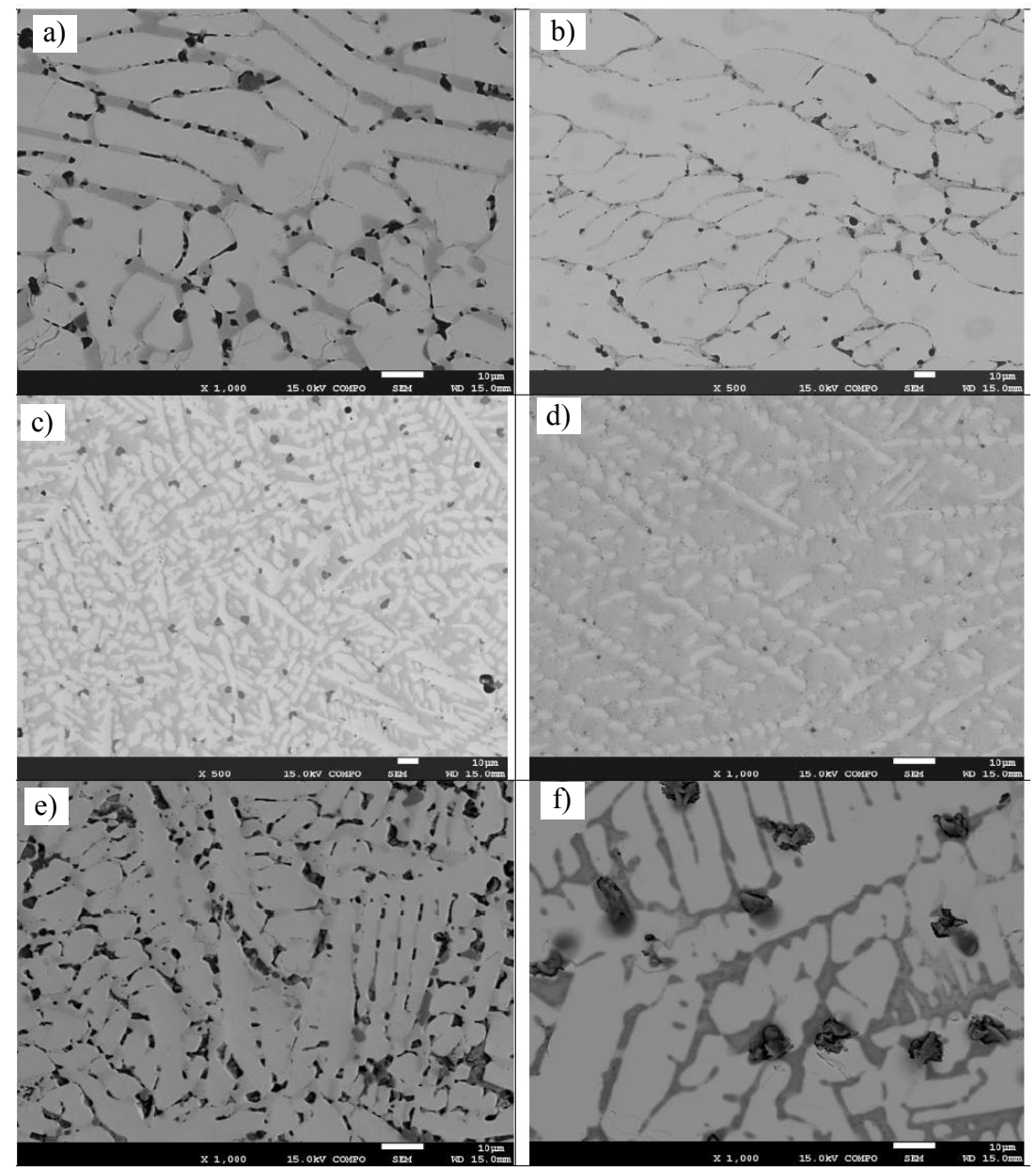

Fig. 2. Electron microphotographs of the alloys: $\mathrm{Y}_{62.5} \mathrm{Cu}_{7} \mathrm{Ge}_{30.5}$ (a);

$\mathrm{Y}_{62.5} \mathrm{Cu}_{3} \mathrm{Ge}_{34.5}$ (b); $\mathrm{Y}_{50} \mathrm{Cu}_{30} \mathrm{Ge}_{20}$ (c); $\mathrm{Y}_{50} \mathrm{Cu}_{40} \mathrm{Ge}_{10}$ (d); $\mathrm{Y}_{62} \mathrm{Cu}_{15} \mathrm{Ge}_{23}(\mathrm{e})$ and $\mathrm{Y}_{62.5} \mathrm{Cu}_{10} \mathrm{Ge}_{27.5}(\mathrm{f})$ 
Crystallographic characteristics of the ternary compounds in the Y-Cu-Ge system

\begin{tabular}{|c|c|c|c|c|c|c|}
\hline \multirow{2}{*}{${ }^{*} \mathrm{No}$} & Compound & Space group & Structure type & \multicolumn{3}{|c|}{ Lattice parameters, $\mathrm{nm}$} \\
\cline { 5 - 7 } & & & & \multicolumn{2}{|c|}{$b$} & - \\
\hline 1 & $\mathrm{YCuGe}$ & $P 6_{3} m c$ & $\mathrm{LiGaGe}$ & $0.42223(1)$ & $0.73306(3)$ \\
\hline 2 & $\mathrm{Y}_{3} \mathrm{Cu}_{4} \mathrm{Ge}_{4}$ & $I m m m$ & $\mathrm{Gd}_{3} \mathrm{Cu}_{4} \mathrm{Ge}_{4}$ & $0.4183(2)$ & $0.6639(1)$ & $1.3932(8)$ \\
\hline 3 & $\mathrm{YCu}_{2} \mathrm{Ge}_{2}$ & $I 4 / m m m$ & $\mathrm{CeAl}_{2} \mathrm{Ga}_{2}$ & $0.4025(4)$ & - & $1.0282(9)$ \\
\hline 4 & $\mathrm{YCu}_{0.67} \mathrm{Ge}_{1.33}$ & $P 6 / m m m$ & $\mathrm{AlB}_{2}$ & $0.40878(3)$ & $0.40028(5)$ \\
\hline 5 & $\mathrm{YCu}_{0.3} \mathrm{Ge}_{2}$ & $C m c m$ & $\mathrm{CeNiSi}_{2}$ & $0.40935(1)$ & $1.63018(7)$ & $0.39630(1)$ \\
\hline 6 & $\mathrm{Y}_{2} \mathrm{CuGe}_{6}$ & $A m m 2$ & $\mathrm{Ce}_{2} \mathrm{CuGe}_{6}$ & $0.41071(2)$ & $0.39955(2)$ & $2.0937(1)$ \\
\hline
\end{tabular}

Note: * The compounds number corresponds to the figure in the phase diagram (Fig. 1)

Experimental details and crystallographic data for YcuGe and $\mathrm{YCu}_{0.30} \mathbf{G e}_{2}$

\begin{tabular}{|c|c|c|}
\hline Alloy composition & $\mathrm{Y}_{34} \mathrm{Cu}_{33} \mathrm{Ge}_{33}$ & $\mathrm{Y}_{30} \mathrm{Cu}_{10} \mathrm{Ge}_{60}$ \\
\hline Refined composition & $\mathrm{YCuGe}$ & $\mathrm{YCu}_{0.30(4)} \mathrm{Ge}_{2}$ \\
\hline EPMA composition & $\mathrm{Y}_{32.96} \mathrm{Cu}_{33.37} \mathrm{Ge}_{33.67}$ & $\mathrm{Y}_{31.86} \mathrm{Cu}_{9.07} \mathrm{Ge}_{59.07}$ \\
\hline Space group & $P 6_{3} m c$ (No. 186) & Cmcm (No. 63) \\
\hline Pearson symbol & $h P 6$ & $o S 16$ \\
\hline$M_{\mathrm{r}} / Z$ & $149.3 / 2$ & $253.15 / 4$ \\
\hline Unit-cell parameters: & $0.42223(1)$ & $0.40935(1)$ \\
\hline$b, \mathrm{~nm}$ & - & $1.63018(7)$ \\
\hline$c, \mathrm{~nm}$ & $0.73306(3)$ & $0.39630(1)$ \\
\hline Calculated density $D_{x}, \mathrm{~g} / \mathrm{cm}^{3}$ & 6.577 & 6.365 \\
\hline Diffractometer & \multicolumn{2}{|c|}{$\begin{array}{l}\text { STOESTADIP (transmission mode, curved Ge(111) monochromator on } \\
\text { primary beam) }\end{array}$} \\
\hline Radiation, wavelength $\lambda, \AA$ & \multicolumn{2}{|c|}{$\mathrm{Cu} K \alpha_{1}, 1.540598$} \\
\hline $\begin{array}{l}\text { Angular range for data collection / increment } \\
\qquad\left({ }^{\circ} 2 \theta\right)\end{array}$ & $6.000 \leq 2 \theta \leq 110.625 / 0.015$ & $6.000 \leq 2 \theta \leq 120.585 / 0.015$ \\
\hline \multirow[t]{4}{*}{ Half width parameters: } & $0.144(5)$ & $0.223(8)$ \\
\hline & $-0.012(9)$ & $-0.098(8)$ \\
\hline & $0.014(2)$ & $0.032(2)$ \\
\hline & $0.567(7)$ & $0.377(7)$ \\
\hline \multirow[t]{2}{*}{ Asymmetry parameters } & $0.021(1)$ & $0.029(6)$ \\
\hline & $0.009(1)$ & $-0.005(1)$ \\
\hline \multirow[t]{2}{*}{ Reliability factors: } & 0.0449 & 0.0479 \\
\hline & 0.0419 & 0.0349 \\
\hline Content of $\mathrm{YCuGe} / \mathrm{Y}(\mathrm{Cu}, \mathrm{Ge})_{2}$ phases, wt $\%$ & $95.4(8) / 4.6(2)$ & \\
\hline Content of $\mathrm{YCu}_{0.30} \mathrm{Ge}_{2} / \mathrm{Y}_{2} \mathrm{CuGe}_{6}$ phases, wt $\%$ & & $80.2(4) / 19.8(2)$ \\
\hline
\end{tabular}

\subsection{Crystal Structure}

According to the literature data compounds $\mathrm{RCu}_{1-x} \mathrm{Ge}_{2}$ with a defect $\mathrm{CeNiSi}{ }_{2}$-type have been found previously for the most rare earths [10] except $\mathrm{Eu}, \mathrm{Yb}$ and Y. In our work at high Ge content we have confirmed the existence of the $\mathrm{Y}_{2} \mathrm{CuGe}_{6}$ compound [1] and identified a new ternary phase with $\sim \mathrm{Y}_{30} \mathrm{Cu}_{10} \mathrm{Ge}_{60}$ composition. The powder pattern of the $\mathrm{Y}_{30} \mathrm{Cu}_{10} \mathrm{Ge}_{60}$ sample was indexed well on the basis of the orthorhombic lattice with cell parameters $a=0.40935(1) \mathrm{nm}, b=1.63018(7) \mathrm{nm}$, 
$c=0.39630(1) \mathrm{nm}$. An analysis of the intensities and calculated lattice parameters indicated that this compound belongs to the $\mathrm{CeNiSi}_{2}$ type structure (space group $\mathrm{Cmcm}$ ). Experimental details of the structure refinements are gathered in Table 3.

During the structure calculations the presence of the second phase $\mathrm{Y}_{2} \mathrm{CuGe}_{6}\left(\mathrm{Ce}_{2} \mathrm{CuGe}_{6}\right.$-type $)$ was taken into account. The refined atomic and isotropic displacement parameters are listed in Table 4. The observed, calculated and difference in X-ray diffraction patterns for the $\mathrm{Y}_{30} \mathrm{Cu}_{10} \mathrm{Ge}_{60}$ sample are shown in Fig. 3 . The data of the crystal structure refinements indicated partial occupation of the $4 c$ crystallographic site by $\mathrm{Cu}$ atoms and the chemical formula of the compound can be expressed as $\mathrm{YCu}_{0.3} \mathrm{Ge}_{2}$.

The first results concerning $\mathrm{YCuGe}$ compound were reported by Rieger et al. [18]. The authors identified $\mathrm{YCuGe}$ compound with the $\mathrm{AlB}_{2}$ structure type in arcmelted alloys and established its homogeneity range $\left(\mathrm{YCu}_{1-0.67} \mathrm{Ge}_{1-1.33}\right)$. Later for the $\mathrm{YCuGe}$ germanide pre-

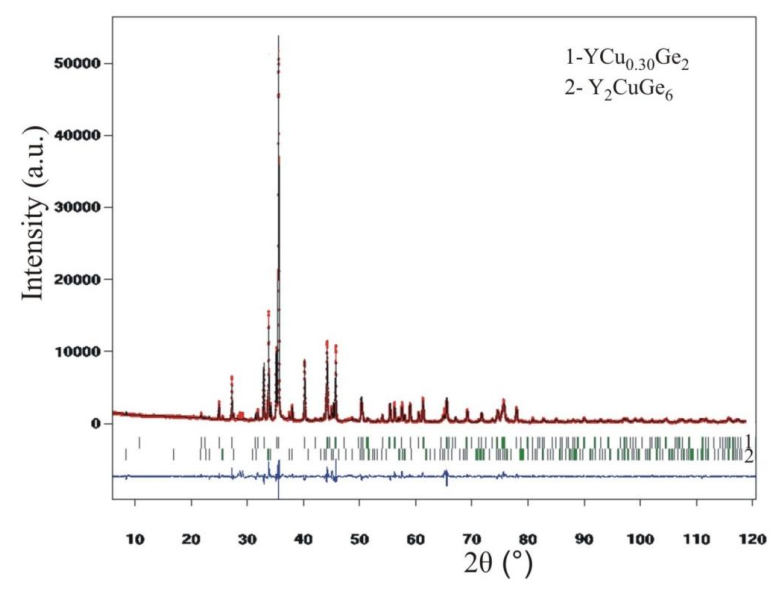

Fig. 3. The observed, calculated and difference in X-ray diffraction patterns for $\mathrm{Y}_{30} \mathrm{Cu}_{10} \mathrm{Ge}_{60}$ sample pared by induction melting and annealed at $1023 \mathrm{~K}$ the $\mathrm{CaIn}_{2}$-type was reported by Jandelli et al. [2]. To clarify this situation, we performed crystal structure refinements of the $\mathrm{YCuGe}$ compound identified in our work at equiatomic composition. Detailed crystal structure investigation performed on the $\mathrm{Y}_{33} \mathrm{Cu}_{33} \mathrm{Ge}_{34}$ sample (annealed at $870 \mathrm{~K}$ ) showed that this structure belongs to the LiGaGe structure type (space group $P 6_{3} m c$ ) [19] which is a ternary ordered variant of the $\mathrm{CaIn}_{2}$ structure. The refined atomic and isotropic displacement parameters are listed in Table 4. In the course of structure refinements, the presence of the second phase $\mathrm{YCu}_{0.67} \mathrm{Ge}_{1.33}\left(\mathrm{AlB}_{2}\right.$-type) was taken into account. The observed, calculated and difference in X-ray diffraction patterns for the $\mathrm{Y}_{33} \mathrm{Cu}_{33} \mathrm{Ge}_{34}$ sample are shown in Fig. 4.

Therefore, performed studies have established the formation of the two separated hexagonal phases along isoconcentrate of 33 at \% Y-YCuGe compound (LiGaGetype) with stoichiometry $1: 1: 1$, and the $\mathrm{YCu}_{0.67} \mathrm{Ge}_{1.33}$ phase $\left(\mathrm{AlB}_{2}\right.$-type $)$ at higher Ge-content.

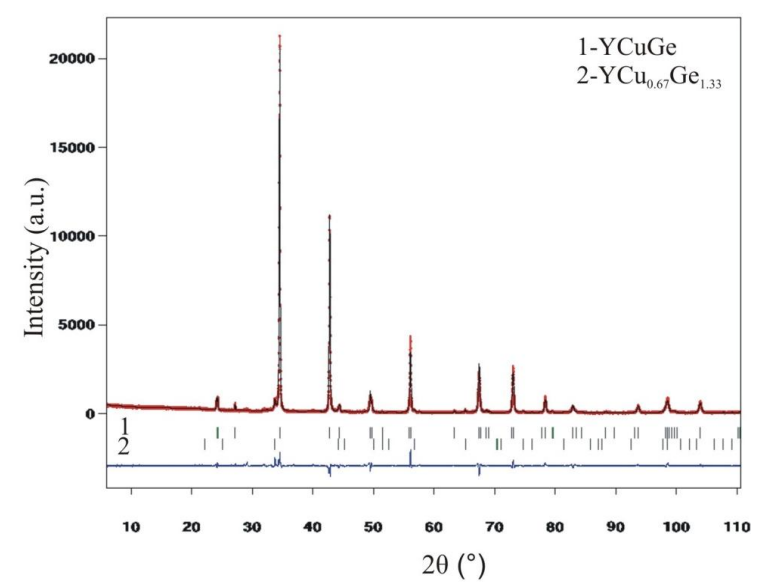

Fig. 4. The observed, calculated and difference in X-ray diffraction patterns for the $\mathrm{Y}_{33} \mathrm{Cu}_{33} \mathrm{Ge}_{34}$ sample

Fractional atomic coordinates, site occupations $(G)$ and isotropic displacement parameters $B_{\text {iso }}$ for $\mathrm{YcuGe}$ and $\mathrm{YCu}_{0.30} \mathrm{Ge}_{2}$

\begin{tabular}{|c|c|c|c|c|c|c|}
\hline Atom & Wyckoff position & $x$ & $y$ & $z$ & $G$ & $B_{\text {iso }} \AA^{2}$ \\
\hline \multicolumn{7}{|c|}{ YCuGe } \\
\hline $\mathrm{Y}$ & $2 a$ & 0 & 0 & 0.25 & 1 & $0.78(3)$ \\
\hline $\mathrm{Cu}$ & $2 b$ & $1 / 3$ & $2 / 3$ & $0.0023(7)$ & 1 & $1.47(9)$ \\
\hline $\mathrm{Ge}$ & $2 b$ & $1 / 3$ & $2 / 3$ & $0.4767(6)$ & 1 & $0.48(6)$ \\
\hline \multicolumn{7}{|c|}{$\mathrm{YCu}_{0.30} \mathrm{Ge}_{2}$} \\
\hline $\mathrm{Y}$ & $4 c$ & 0 & $0.1042(1)$ & $1 / 4$ & 1 & $0.19(3)$ \\
\hline $\mathrm{Cu}$ & $4 c$ & 0 & $0.3127(4)$ & $1 / 4$ & $0.30(4)$ & $0.57(5)$ \\
\hline $\mathrm{Ge} 1$ & $4 c$ & 0 & $0.4516(1)$ & $1 / 4$ & 1 & $0.89(6)$ \\
\hline $\mathrm{Ge} 2$ & $4 c$ & 0 & $0.7478(1)$ & $1 / 4$ & 1 & $1.43(6)$ \\
\hline
\end{tabular}


Experimental data of microhardness measurement of selected phases in the $\mathrm{Y}$-Cu-Ge system

\begin{tabular}{|c|c|}
\hline Alloy composition/phase/structure type & Microhardness, GPa \\
\hline $\mathrm{Y}_{62} \mathrm{Cu}_{15} \mathrm{Ge}_{23} / \mathrm{Y}_{5} \mathrm{Ge}_{3} / \mathrm{Mn}_{5} \mathrm{Si}_{3}$ & 6.32 \\
\hline $\mathrm{Y}_{62.5} \mathrm{Cu}_{3} \mathrm{Ge}_{34.5} / \mathrm{Y}_{5} \mathrm{Ge}_{3} / \mathrm{Mn}_{5} \mathrm{Si}_{3}$ & 6.83 \\
\hline $\mathrm{Y}_{50} \mathrm{Cu}_{30} \mathrm{Ge}_{20} \mathrm{YCu}_{2} / \mathrm{KHg}_{2}$ & 5.89 \\
\hline $\mathrm{Y}_{50} \mathrm{Cu}_{40} \mathrm{Ge}_{10} / \mathrm{YCu} / \mathrm{CsCl}$ & 3.57 \\
\hline
\end{tabular}

\subsection{Microhardness Measurements}

Based on the results of the microstructural studies, the microhardness of individual phases of the alloys with different compositions corresponding to a binary or ternary compound was measured. Eight indents were performed on each phase to verify the accuracy of the indentation data. The Vickers hardness measurements showed that the microhardness values decrease with decreasing Ge-content in the alloys (Table 5). Higher microhardness value was observed for $\mathrm{Ge}$-containing phase $\mathrm{Y}_{5} \mathrm{Ge}_{3}$ as compared with $\mathrm{YCu}$ and $\mathrm{YCu}_{2}$ phases.

The hardness of the intermetallic compounds is usually higher than that of the individual components. Experimental microhardness values for both $\mathrm{YCu}$ and $\mathrm{YCu}_{2}$ compounds are much higher (Table 5) in comparison with elemental copper and yttrium ( 0.34 and $0.97-0.98 \mathrm{GPa}$, respectively) [20]. As reported in [21], the measured microhardness value for $\mathrm{Y}_{3} \mathrm{Ge}_{4}$ binary $(9.42 \mathrm{GPa})$ is higher than elemental Ge $(8.99 \mathrm{GPa})$, but increased $\mathrm{Y}$ content in the $\mathrm{Y}_{5} \mathrm{Ge}_{3}$ phase results in lower microhardness value ( 6.77 GPa) in comparison with Ge. Microhardness measurements of some Cr-containing compounds, $\mathrm{Cr}_{3} \mathrm{Ge}(9.47 \mathrm{GPa}), \mathrm{YCr}_{6} \mathrm{Ge}_{6}(10.04 \mathrm{GPa})$ [21], showed much higher values (microhardness values for chromium are $0.66-0.69 \mathrm{GPa}$ ) compared to $\mathrm{Cu}-$ containing phases. Analyzed data illustrate the influence of both nature of the transition metal and the germanium content on microhardness of the studied intermetallics.

\subsection{Comparison of the Component \\ Interaction in the R-Cu-Ge Systems}

Similar to the Er-Cu-Ge system [11], in the Y-Cu$\mathrm{Ge}$ system equiatomic $\mathrm{YCuGe}$ compound belongs to the LiGaGe-type, while $\mathrm{YCu}_{0.67} \mathrm{Ge}_{1.33}$ germanide with $\mathrm{AlB}_{2^{-}}$ type was realized at higher $\mathrm{Ge}$ content. $\mathrm{LiGaGe}$ structure type (space group $P 6_{3} m c$ ) represents a ternary noncentrosymmetric ordered variant of the $\mathrm{CaIn}_{2}$-type (space group $\mathrm{P}_{3} / \mathrm{mmc}$ ) with splitting of the $4 f$ position in two $2 b$ positions and consequent change of the space group $P 6_{3} / m m c \rightarrow P 6_{3} m c$. Both structure types are derivative form of the $\mathrm{AlB}_{2}$-type (space group P6/mmm) [22]. In comparison with the $\mathrm{AlB}_{2}$-type the $\mathrm{LiGaGe}$ and $\mathrm{CaIn}_{2}$ structures are characterized by a nearly doublet parameter $c$. Structural analysis showed that the most structures of the ternary compounds realized in the $\mathrm{Y}-\mathrm{Cu}-\mathrm{Ge}$ system contain the fragment of the $\mathrm{AlB}_{2}$-type (Fig. 5).

Comparing now the investigated $\mathrm{Y}-\mathrm{Cu}-\mathrm{Ge}$ and previously studied $\mathrm{R}-\mathrm{Cu}-\mathrm{Ge}$ systems with heavy rare earths $[1,11,12]$, a close analogy in the stoichiometry and crystal structure of the most formed compounds should be noted. Similarity in the interaction of the elements in all investigated systems is illustrated by the formation of the compounds $\mathrm{RCuGe}, \mathrm{R}_{3} \mathrm{Cu}_{4} \mathrm{Ge}_{4}, \mathrm{RCu}_{2} \mathrm{Ge}_{2}$ and $\mathrm{R}_{2} \mathrm{CuGe}_{6}$.
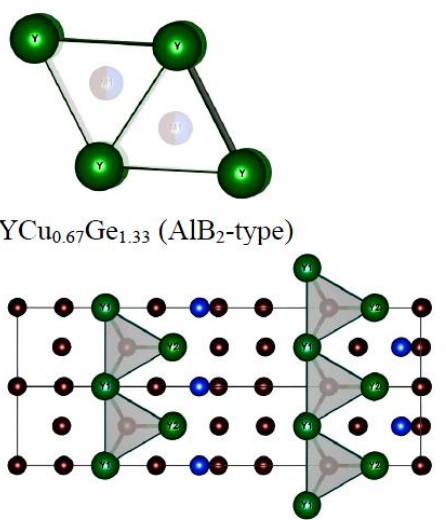

$\mathrm{Y}_{2} \mathrm{CuGe}_{6}\left(\mathrm{Ce}_{2} \mathrm{CuGe}_{6}\right.$-type $)$

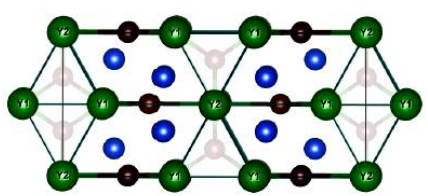

$\mathrm{Y}_{3} \mathrm{Cu}_{4} \mathrm{Ge}_{4}\left(\mathrm{Gd}_{3} \mathrm{Cu}_{4} \mathrm{Ge}_{4}\right.$-type $)$

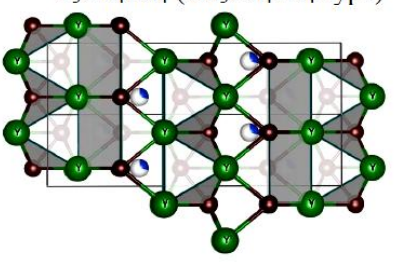

$\mathrm{YCu}_{0.3} \mathrm{Ge}_{2}\left(\mathrm{CeNiSi}_{2}\right.$-type $)$

Fig. 5. Fragment of the $\mathrm{AlB}_{2}$ structure type in the $\mathrm{Y}_{3} \mathrm{Cu}_{4} \mathrm{Ge}_{4}, \mathrm{YCu}_{0.3} \mathrm{Ge}_{2}$ and $\mathrm{Y}_{2} \mathrm{CuGe}_{6}$ compounds 
The feature of the $\mathrm{R}-\mathrm{Cu}-\mathrm{Ge}$ systems concerns the $\mathrm{RCuGe}$ and $\mathrm{R}(\mathrm{Cu}, \mathrm{Ge})_{2}$ ternary phases. $\mathrm{RCuGe}$ germanides, where $\mathrm{R}$ are light rare earths, crystallize in the $\mathrm{AlB}_{2}$-type whereas for rare earths of Yttrium group equiatomic compounds belong to the $\mathrm{CaIn}_{2}$ (or ordered $\mathrm{LiGaGe})$ type structure and the ternary phases $\mathrm{R}(\mathrm{Cu}, \mathrm{Ge})_{2}$ with $\mathrm{AlB}_{2}$-type were realized at deviated composition along 33 at $\%$ of $\mathrm{R}$. Contrary to the $\mathrm{AlB}_{2}$-type equiatomic compounds with $\mathrm{Ce}$ and $\mathrm{Eu}$, the existence of the equiatomic $\mathrm{CeCuGe}$ and $\mathrm{EuCuGe}$ germanides with $\mathrm{CaIn}_{2-}$ type was found at higher annealing temperature (1073 K) [23]. The EuCuGe compound with the orthorhombic HoNiGa-type was realized in the Eu-Cu-Ge system at $670 \mathrm{~K}$ [24]. As a conclusion, the formation of the $\mathrm{R}(\mathrm{Cu}, \mathrm{Ge})_{2}$ and $\mathrm{RCuGe}$ compounds depends on both the nature of the rare earths and the temperature of annealing.

Analysis of the studied $\mathrm{Y}-\{\mathrm{V}, \mathrm{Cr}, \mathrm{Mn}, \mathrm{Fe}, \mathrm{Ni}, \mathrm{Cu}\}$ Ge ternary systems $[1,21,25,26]$ showed a significant influence of the transition metal (filling its $d$-level) on interaction between the components. Passing from $\mathrm{V}$ to $\mathrm{Ni}$ leads to complication of the phase equilibrium diagrams and increasing the number of the ternary compounds (from one ternary compounds in the Y-V-Ge system [25] to 12 compounds in the $\mathrm{Y}-\mathrm{Ni}-\mathrm{Ge}$ system [1]). The number of intermediate phases is reduced to six in the $\mathrm{Y}-\mathrm{Cu}-\mathrm{Ge}$ system, which agrees well with the electronic configuration of the transition metal atoms.

\section{Conclusions}

Phase equilibria of the $\mathrm{Y}-\mathrm{Cu}-\mathrm{Ge}$ system were established by XRPD and EPM analyses in the whole concentration range and isothermal section at $870 \mathrm{~K}$ was constructed. Six ternary phases were formed under applied conditions. The crystal structure of the new ternary compound $\mathrm{YCu}_{0.3} \mathrm{Ge}_{2}$ with $\mathrm{CeNiSi}_{2}$ structure type was determined by powder diffraction method.

It was established that equiatomic $\mathrm{YCuGe}$ compound belongs to the LiGaGe-type, while $\mathrm{YCu}_{0.67} \mathrm{Ge}_{1.33}$ germanide with $\mathrm{AlB}_{2}$-type exists at higher Ge content.

The Vickers hardness measurements showed that the microhardness values decrease with decreasing Gecontent in the alloys.

\section{Acknowledgements}

The research was supported by the Ministry of Education and Science of Ukraine under Grant No. 0118 U003609.

\section{References}

[1] Salamakha P., Sologub O., Bodak O.: Ternary Rare-Earth Germanium Systems [in]: Gschneidner K. (Ed.), Handbook on the Physics and Chemistry of Rare Earths. The Netherlands, Amsterdam 1999, 1-223.

[2] Jandelli A.: J. Alloys Compd., 1993, 198, 141. https://doi.org/10.1016/0925-8388(93)90157-I

[3] Rieger W.: Monatsh. Chem., 1970, 101, 449.

https://doi.org/10.1007/BF00910230

[4] Rusinek D., Niewolski J., Czub J. et al.: Mater. Sci.-Poland, 2013, 32, 495. https://doi.org/10.2478/s13536-013-0136-2

[5] Konyk M., Romaka L., GorelenkoYu., Bodak O.: J.

AlloysCompd., 2000, 311, 120. https://doi.org/10.1016/S09258388(00)01093-8

[6] Rayaprol S., Sebastian C., Pottgen R.: J. Solid State Chem., 2006, 179, 2041. https://doi.org/10.1016/j.jssc.2006.04.005

[7] Heying B., Rodewald U., Pottgen R. et al:: Monatsh. Chem., 2005, 136, 655. https://doi.org/10.1007/s00706-005-0290-2

[8] Fedyna L., Fedyna M., Fedorchuk A.: Visnyk Lviv Univ. Ser. Chem., 2014, 55, 87.

[9] Baran S., Szytuła A., Leciejewicz J. et al.: J. AlloysCompd., 1996, 243, 112. https://doi.org/10.1016/S0925-8388(96)02399-7 [10] Francois M., Venturini G., Malaman B., Roques B.: J. LessCommon Met.,1990, 160, 197. https://doi.org/10.1016/00225088(90)90381-S

[11] Konyk M., Horyn A., Serkiz R.: Visnuk Lviv Univ. Ser. Chem., 2012, 53, 42.

[12] Fedyna L., Bodak O., Tokaychuk Ya. et al.: J. Alloys Compd., 2004, 367, 70. https://doi.org/10.1016/j.jallcom.2003.08.014

[13] Massalski T.: Binary Alloy Phase Diagrams. ASM, Metals Park, Ohio 1990.

[14] Villars P., Calvert L.: Pearson's Handbook of Crystallographic Data for Intermetallic Phases. ASM, Metals Park, Ohio 1991.

[15] Okamoto H.: Phase Diagrams for Binary Alloys. American Society for Metals, Materials Park, Ohio2000.

[16] Ijjaali I., Venturini G., Malaman B.: J. Alloys Compd., 1999,

284, 237. https://doi.org/10.1016/S0925-8388(98)00941-4

[17] Rodriguez-Carvajal J.: Newsletters, 2001, 26, 12.

http://www.iucr.org/iucr-top/comm/cpd/Newsletters/

[18] Rieger W., Parthe E.: Monatsh. Chem., 1969, 100, 439. https://doi.org/10.1007/BF00904085

[19] Bockelmann W., Schuster H.: Z. Anorg. Allg. Chem., 1974, 410, 233. https://doi.org/10.1002/zaac. 19744100303

[20] Steinberg S.: Metall Science. Metallurgizdat, Sverdlovsk 1961. [21] Konyk M., Romaka L., Orovcik L. et al.: Visnyk Lviv. Univ. Ser. Chem., 2019, 60, 38. https://doi.org/10.30970/vch.6001.038 [22] Hofmann R.-D., Pottgen R.: Z. Kristallogr., 2001, 216, 127. https://doi.org/10.1524/zkri.216.3.127.20327

[23] Yang F., Kuang J., Li J. et al.: J. Appl. Phys., 1991, 69, 4705. https://doi.org/10.1063/1.348279

[24] Belan B., Manyako M., Pukas S., Gladyshevskii R.: Chem. Met. Alloys, 2015, 8, 63. https://doi.org/10.30970/cma8.0313

[25] Konyk M.,Romaka L., Stadnyk Yu. et al.: Visnyk Lviv Univ. Ser. Chem., 2018, 59, 11. https://doi.org/10.30970/vch.5901.011 [26] Konyk M., Romaka L., Horyn A. et al.: Visnyk Lviv. Univ. Ser. Chem., 2015, 56, 25.

Received: June 05, 2019 / Revised: August 12, 2019 / Accepted: December 05, 2019 


\section{ЕКСПЕРИМЕНТАЛЬНЕ ДОСЛІДЖЕННЯ СИСТЕМИ Y-CU-GE 3A $870 \mathrm{~K}$}

Анотація. Діаграма фазових рівноваг потрійної системи Y-Cu-Ge побудована за $870 \mathrm{~K}$ методами рентгенівської дифракиії, металографічного аналізу і енергодисперсійної рентгенівської спектроскопії в повному концентраиійному інтервалі. Встановлено утворення шести тернарних сполук YCuGe (структурний тип $\mathrm{LiGaGe}$ ), $\mathrm{YCu}_{2} \mathrm{Ge}_{2}$ (структурний тип $\mathrm{CeAl}_{2} \mathrm{Ga}_{2}$ ), $\quad \mathrm{Y}_{3} \mathrm{Cu}_{4} \mathrm{Ge}_{4}$ (структурний тип $\mathrm{Gd}_{3} \mathrm{Cu}_{4} \mathrm{Ge}_{4}$ ), $\mathrm{Y}_{2} \mathrm{CuGe}_{6}$ (структурний тип $\mathrm{Ce}_{2} \mathrm{CuGe}$ ), $\mathrm{YCu}_{0.67} \mathrm{Ge}_{1.33}$ (структурний тип $\mathrm{AlB}_{2}$ ) $i \mathrm{YCu}_{0.3} \mathrm{Ge}_{2}$ (структурний тип $\mathrm{CeNiSi}$ ).

Ключові слова: інтерметаліди, фазова діаграма, рентгенівська дифракція, кристалічна структура. 